\section{Efficiency of a digital electrofulguration system in contaminated root canals in vitro}

Cimara B. B. Silva (D) 2, Juliana D. Bronzato (D) 1, Daniel R. Herrera (iD 1, 3 , Francisco Montagner (10) ${ }^{1,4}$, Elifas L. Nunes (i) ${ }^{1,5}$, Brenda P F A Gomes (i) 1

Decontamination of the root canal (RC) system is essential for successful endodontic therapy. In this in vitro study, it was evaluated the disinfection potential of an electrofulguration device, the Endox ${ }^{\circledR}$ Endodontic System (EES), in RC infected with Enterococcus faecalis. Sixty-five human lower premolars were instrumented with $\mathrm{MTw}^{\circledR}{ }^{\circledR}$ system. The specimens were distributed into six experimental groups $(n=10)$, according to the irrigation protocol: $2 \%$ chlorhexidine gel (CHX); $\mathrm{CHX}+\mathrm{EES} ; 5.25 \%$ sodium hypochlorite $(\mathrm{NaOCl}) ; \mathrm{NaOCl}+\mathrm{EES}$; saline solution (SS); and SS + EES. Five specimens were untreated (control). RC samples were collected before (C1) and after EES treatment (C2), after chemo-mechanical preparation (CMP) (C3), and after final EES treatment (C4). All samples were plated for colony forming units $(\mathrm{CFU} / \mathrm{mL})$ onto solid media. The data were analyzed by Wilcoxon and Friedman tests for intragroup comparisons and by Kruskal Wallis test followed by Dunn's test for intergroup comparisons $(\alpha=0.05)$. Treatment with the EES did not significantly reduce the number of CFU $/ \mathrm{mL}$ as compared to baseline levels ( 1 vs. $\mathrm{C} 2, \mathrm{p}>0.05)$. After CMP (C3), all groups showed a significantly reduced amount of $\mathrm{CFU} / \mathrm{mL}(p<0.05)$, with no difference between $\mathrm{CHX}$ - and $\mathrm{NaOCl}$-treated samples ( $p>0.05$ ). Lastly, treatment with the EES following CMP (C4) did not significantly reduce the amount of $\mathrm{CFU} / \mathrm{mL}$ (C3 vs. C4, p> 0.05). To conclude, the use of the Endox ${ }^{\circledR}$ Endodontic System did not result in considerable bacterial reduction at all operative times, while treatment with $\mathrm{NaOCl}$ and $\mathrm{CHX}$ was equally efficient for this purpose.
1 - Department of Restorative Dentistry, Division of Endodontics, Piracicaba Dental School, State University of CampinasUNICAMP, Piracicaba, SP, Brazil.

2 - Department of Endodontics, State University of Amazonas, Manaus, MA, Brazil. 3 - Department of Endodontics, Federal Fluminense University, Niteroi, RJ, Brazil 4 - Department of Conservative Dentistry, Division of Endodontics, Federal University of Rio Grande do Sul, Porto Alegre, RS, Brazil. 5 - Dental Surgeon, Piracicaba, SP, Brazil

Correspondence: Brenda PFA Gomes, Avenida Limeira, 901, Piracicaba, SP, 13414-018, Brazil. E-mail address: bpgomes@unicamp.br Phone: $+551921065200$

Key Words: endodontics, root canal irrigants, Enterococcus faecalis.

\title{
Introduction
}

The major purpose of endodontic therapy lies in the cleansing and disinfection of the root canal system. The occurrence of bacteria and their byproducts is the main factor triggering the onset of periapical inflammation (1). Enterococcus faecalis is a Gram-positive facultative anaerobic bacterium that is often associated with persistent apical periodontitis, flare-up cases, secondary infections, and retreatment cases with persistent lesions (2). This pathogen can survive inside the dentinal tubules and resist a wide variety of antimicrobial treatments (2). Several endodontic instruments and supplies with the most varied characteristics as well as different instrumentation protocols have been recurrently proposed to improve the outcomes of endodontic therapy. Moreover, auxiliary chemical substances (ACS), in association with mechanical debridement, play a central role in the disinfection of the root canal system (3).

A well-known example of ACS is sodium hypochlorite ( $\mathrm{NaOCI}$ ). It has been widely used as an auxiliary chemical ever since due to its strong antimicrobial properties and soft tissue dissolution capacity (4). $\mathrm{NaOCl}$ is clinically used at concentrations ranging from $0.5 \%$ to over $6 \%$, and despite its numerous known advantages, it presents high cytotoxicity and it may cause severe inflammatory reactions if injected into periapical tissues (5). Another ACS is chlorhexidine (CHX), which possesses a wide range of antimicrobial activity, substantivity (residual antimicrobial activity), lower cytotoxicity than $\mathrm{NaOCl}$, among other properties. $\mathrm{CHX}$ has been recommended as an alternative to $\mathrm{NaOCl}$, especially in cases of open apex, root resorption, foramen enlargement and root perforation, due to its low cytotoxicity to the periapical tissues, or in cases of allergy related to bleaching solutions (6). $\mathrm{CHX}$ has no ability to dissolve organic tissues, but when it is used as the main endodontic irrigant, it has shown a high therapy success rate (7). However, in combination with $\mathrm{NaOCl}$, the success rate might decrease due to the formation of an interaction product (8). 
To date, traditional endodontic procedures have not been able to completely remove the microbial content from the root canal system. This reinforces the need to develop methods complementary to the conventional chemo-mechanical preparation (CMP) to improve root canal disinfection. The Endox ${ }^{\circledR}$ Endodontic System (EES) (Lysis srl, Milano, Italy) is a digital electrofulguration system used in endodontic therapy for two purposes, namely: (i) acts as foraminal locator by impedance (9); and (ii) promotes microbial killing by damaging cell membranes (10). For its use as an aid in root canal disinfection, the EES device is activated and a high-frequency alternating current discharge $(312.5 \mathrm{kHz})$ is generated, thereby vaporizing the eventual microbial content of the canal $(10,11)$.

Previous studies have investigated the effect of Endox ${ }^{\circledR}$ Endodontic System (11-13) against E.faecalis showing its potential antimicrobial activity. However, they have not evaluated the use of Endox ${ }^{\circledR}$ in combination with ACS such as $\mathrm{NaOCl}$ and $\mathrm{CHX}$ in order to increase its antimicrobial effect. In this in vitro study, it was evaluated the bacterial killing efficiency of the Endox ${ }^{\circledR}$ electrofulguration system, associated or not with different ACS and saline, against Enterococcus faecalis in contaminated root canals. The alternative hypothesis was that the Endox ${ }^{\circledR}$ system would improve the root canals disinfection.

\section{Material and Methods}

This study was previously approved by the Research Ethics Committee at Piracicaba Dental School, University of Campinas (FOP/UNICAMP), under protocol no. 114-12.

\section{Selection and Preparation of Specimens}

The sample size was estimated based on a previous study (14). The sample of 10 teeth per group provided the statistical power of $0.8(\beta=0.2)$ with the significance level of $\alpha=0.04$. The sample size calculation was performed using the sample size website (http://calculoamostral.bauru.usp.br/calculoamostral/index.php).

A total of sixty-five extracted human lower premolars were selected. The specimens underwent radiographical examination for selection criteria. Inclusion criteria included teeth with a maximum curvature of $5^{\circ}$ according to the Schneider's classification (15), single-rooted teeth with a single canal and with fully formed apices. Only narrow canals with the initial apical diameter no longer than a size 15 K-file (Dentsply Maillefer, Ballaigues, Switzerland) were included. Teeth with the presence of endodontic treatment, internal or external resorptions, root caries, cracks, and/or calcifications were excluded from the research.

Periodontal Gracey curettes (S. S. White Articles Dentários Ltda., Juiz de Fora, MG, Brazil) were used to remove residual periodontal tissue. The specimens were sectioned near the cement-enamel junction with a carborundum disc (Carbodent, Gysi S.A., Buenos Aires, Argentina). The teeth crowns were discarded and the length of the roots was standardized to $16 \mathrm{~mm}$.

All the specimens were instrumented up to the apical foramen, defined as working length, with a size $20 \mathrm{~K}$-file (Maillefer, Ballaigues, VD, Switzerland) in order to standardize the apical foramen. To remove the smear layer present in the root canal (16), it was washed with 17\% EDTA for 10 min, 5.25\% $\mathrm{NaOCl}$ for another $10 \mathrm{~min}$, under constant stirring (Fanem Heater-Stirrer, Fanem Ltda, São Paulo, SP, Brazil), followed by further washing with buffered phosphate solution for another 10 min to remove traces of EDTA and $\mathrm{NaOCl}(16)$. The specimens were subsequently immersed in distilled water for 1 hour to remove all possible traces of the previously used chemical substances (17).

The specimens were distributed into six groups ( $n=10 /$ group) plus an untreated control group ( $n$ $=5$ ). Samples were randomly selected using the Research Randomizer software (18). The specimens were placed in screw-capped glass vials containing $100 \mathrm{~mL}$ of Brain Heart Infusion (BHI) broth and were autoclaved. After, the flasks were kept at $37{ }^{\circ} \mathrm{C}$ in a $5 \% \mathrm{CO} 2$ incubator for $48 \mathrm{~h}$ to undergo a sterility test (19).

\section{Specimen Contamination Protocol}

Enterococcus faecalis ATCC 29212 cultures grown in BHI broth (Difco, Detroit, MI, USA) were used in this study. The specimen contamination protocol was previously described (19-22). Briefly, frozen stocks were subcultured onto $\mathrm{BHI}$ agar added of 5\% sheep defibrinated blood and incubated at $37^{\circ} \mathrm{C}$ in $10 \%$ CO2 atmosphere for $24 \mathrm{~h}$. The inoculum was adjusted to match the standard 2.0 of the McFarland scale. Each vial with the teeth was sealed and incubated at $37^{\circ} \mathrm{C}$ for 21 days, with replacement of the media every two days. 
Bacterial growth was indicated by turbidity of the medium, and culture purity was confirmed by the morphology of the colonies on $\mathrm{BHI}$ blood agar. To visualize the bacterial colonization in the root canal, control specimens $(n=5)$ were submitted to scanning electron microscopy (SEM) analysis and served as control samples for bacterial growth. The specimen preparation for SEM was previously described (16).

The specimens were placed on a sterilized metallic platform inside a stainless-steel case filled with $0.9 \%$ saline solution. The teeth roots were put in contact with saline to create an electric circuit, as it is a conductive solution. Each root was irrigated with $1 \mathrm{~mL}$ of saline, and microbiological samples from the contaminated root canal were collected (Collection 1, C1) (Figure 1).

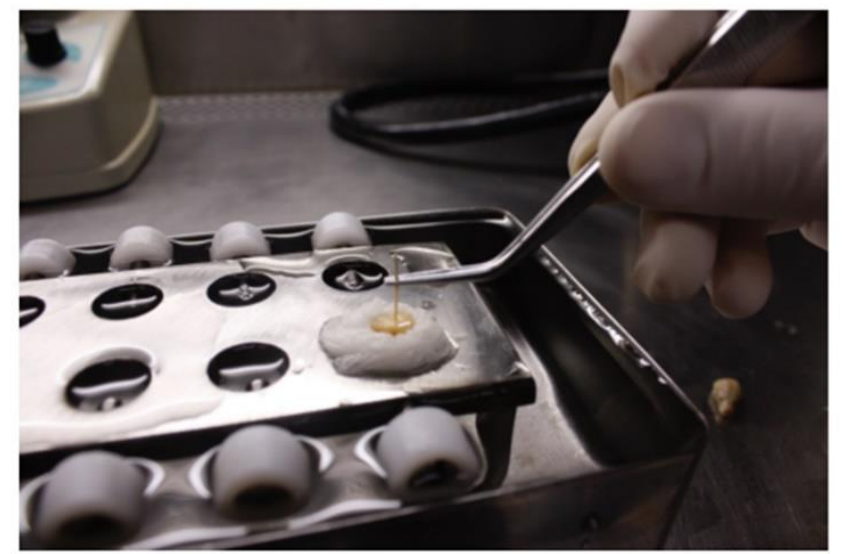

Figure 1. Specimen placed on a sterilized metallic platform inside a stainless-steel case filled with $0.9 \%$ saline solution during Collection 1.

\section{Disinfection Protocols}

The study groups and their corresponding disinfection protocols can be found in Table 1.

Table 1. Distribution of disinfection protocols groups ( $\mathrm{n}=10$ / group) and control $(\mathrm{n}=5)$.

\begin{tabular}{cc}
\hline Group & Disinfection Protocol \\
\hline $\mathrm{S}$ & Saline $(0.9 \% \mathrm{NaCl})$ \\
$\mathrm{S}+\mathrm{EES}$ & Saline + EES \\
$\mathrm{CHX}$ & $2 \% \mathrm{CHX}$ gel \\
$\mathrm{CHX}+\mathrm{EES}$ & $\mathrm{CHX}+\mathrm{EES}$ \\
$\mathrm{NaOCl}$ & $5.25 \% \mathrm{NaOCl}$ \\
$\mathrm{NaOCl}+\mathrm{EES}$ & $\mathrm{NaOCl}+\mathrm{EES}$ \\
$\mathrm{Control}$ & Untreated \\
\hline Note: S: Saline solution; EES: Endox $^{\circledR}$ Endodontic System; CHX: Chlorhexidine.
\end{tabular}

All groups were initially flooded with $5 \mathrm{~mL}$ of saline. In the groups in which the Endox ${ }^{\circledR}$ system was used, the system's red probe ( $24 \mathrm{~mm}$ in length and $0.15 \mathrm{~mm}$ in diameter) was inserted into the root canal and one pulse was emitted at each third of the root canal (cervical, middle and apical) at $312.5 \mathrm{kHz}$ and $110 \mathrm{~W} / 140 \mathrm{~ms}$, following the manufacturer's specifications. Afterwards, a new sample collection was performed (C2) only in these groups.

All teeth were then instrumented by the Mtwo ${ }^{\circledR}$ system following the basic technique recommended by the manufacturer. The root canal was prepared by each instrument in a sequential order (20/.06, $25 / .06,30 / .05,35 / .04$ ) to full working length using a brushing movement, without exerting any pressure. The irrigation protocol was performed at a flow rate of $5 \mathrm{~mL} / \mathrm{min}$ as follows: $5 \mathrm{~mL}$ of saline in the $S$ and $\mathrm{S}+\mathrm{EES}$ groups each time the file was changed; $1 \mathrm{~mL} 2 \%$ chlorhexidine gel (Endogel, Itapetininga, SP, Brazil) to fill up the canal followed by $4 \mathrm{~mL}$ of saline after each new instrument in the CHX group; and $1 \mathrm{~mL} 2 \%$ chlorhexidine gel followed by $4 \mathrm{~mL}$ of saline after each new instrument (CHX + EES group); 5 $\mathrm{mL}$ of $5.25 \% \mathrm{NaOCl}$ (Proderma Manipulation Pharmacy, Piracicaba, SP, Brazil) at each instrument change $(\mathrm{NaOCl}$ and $\mathrm{NaOCl}+\mathrm{EES}$ groups). 
The ACS was delivered using $5 \mathrm{~mL}$ syringes (Med Goldman, Manaus, AM, Brazil) and BD 0.55×20$24 \mathrm{G}$ needles (Becton Dickinson Surgical Industries S.A., Juiz de Fora, MG, Brazil). Following the chemomechanical preparation, $5 \mathrm{~mL}$ of different neutralizers were applied into the root canals for 1 minute, as follows: 0.5\% Tween 80 (Sigma Chemical Com, Saint Louis, MO, USA) + 0.07\% soy lecithin (Drogal Manipulation Pharmacy, Piracicaba, SP, Brazil) in the CHX and CHX + EES groups; 5\% sodium thiosulfate (Manipulation Pharmaceutical Proderma, Piracicaba, SP) in the $\mathrm{NaOCl}$ and $\mathrm{NaOCl}+\mathrm{EES}$ groups. Lastly, all specimens were irrigated with $5 \mathrm{~mL}$ of saline solution, and a new sample collection was performed (C3). Again, all canals were flooded with $5 \mathrm{~mL}$ of saline and the Endox ${ }^{\circledR}$ system was used in the groups $\mathrm{S}$ + EES; $\mathrm{NaOCl}+\mathrm{EES}$; and $\mathrm{CHX}+\mathrm{EES}$, as previously described. Then, microbiological samples were collected from these specimens (C4).

\section{Sample Processing}

All microbiological samples from the root canal were collected with sterile absorbent paper cones no. 15 (Tanari Industrial, Manaus, AM, Brazil) placed at the working length for 1 min. Each collection used 4 paper cones. The cones were individually deposited into sterile microcentrifuge tubes (Elkay Products Inc, Shrewsbury, MA, USA) containing $1 \mathrm{~mL}$ of BHI, and the samples were processed immediately after collection. Each tube was vortexed for $1 \mathrm{~min}$ (Marconi Equipamentos para Laboratórios LTDA, Piracicaba, SP, Brazil) and serially diluted to $1 / 10$ and $1 / 100$ in sterile BHI. A hundred-microliter aliquots from the 10-2 dilution were plated in triplicates onto $\mathrm{BHI}$ blood agar and incubated at $37^{\circ} \mathrm{C}$ in $5 \% \mathrm{CO} 2$ for $48 \mathrm{~h}$. Microbial viability was determined by counting the number of colony forming units (CFU/mL).

\section{Statistical Analysis}

The data were initially checked for normality using the Shapiro-Wilk test. The tests indicated that the normality requirement was not reached $(p<0.05)$. The CFU counts were log-transformed before performing the statistical tests. Wilcoxon signed-rank and Friedman tests were used for intragroup comparisons, and Kruskal Wallis test followed by Dunn's test were used for intergroup comparisons. All the tests were performed with the SPSS 22 (SPSS Inc., Chicago, IL, USA) software $(\alpha=0.05)$.

\section{Results}

All specimens showed bacterial growth upon contamination with E. faecalis. Treatment with the EES before CMP of the root canal did not significantly reduce the number of CFU/mL as compared to baseline levels (C1 vs. C2, p> 0.05) (Table 2). 
Table 2. Effects of different treatment modalities on bacterial viability in the root canal at different operative times. The data are expressed as median Log $10 \mathrm{CFU} / \mathrm{mL}$ (min-max), followed by the mean reduction (\%) in comparison with $\mathrm{C} 1$.

\begin{tabular}{|c|c|c|c|c|c|c|c|}
\hline Group & $\mathrm{C} 1$ & $\mathrm{C} 2$ & Reduction (\%) & $\mathrm{C} 3$ & Reduction (\%) & $\mathrm{C} 4$ & Reduction (\%) \\
\hline Saline & $5.25(4.73 \pm 5.75) \mathrm{Aa}$ & - & - & $1.39(0.60 \pm 3.30) \mathrm{Ab}$ & 99.28 & - & - \\
\hline Saline + EES & $5.09(4.56 \pm 5.86) \mathrm{Aa}$ & $4.53(3.30-5.30) \mathrm{Aa}$ & 45.56 & $1.08(0.33 \pm 3.60) \mathrm{Ab}$ & 99.44 & $1.43(0.66 \pm 3.78) \mathrm{Ab}$ & 99.26 \\
\hline CHX & $4.71(3.78 \pm 5.50) \mathrm{Aa}$ & - & - & $0.70(0 \pm 0.66) \mathrm{Bb}$ & 99.99 & - & - \\
\hline CHX +EES & $4.62(3.60 \pm 5.52) \mathrm{Aa}$ & $4.35(3.90-4.87) \mathrm{Aa}$ & 73.54 & $0.60(0 \pm 0.30) \mathrm{Bb}$ & 99.99 & $0.28(0 \pm 0.45) \mathrm{Bb}$ & 99.99 \\
\hline $\mathrm{NaOCl}$ & $4.66(4.20 \pm 5.46) \mathrm{Aa}$ & - & - & $0.60(0 \pm 0,96) \mathrm{Bb}$ & 99.99 & - & - \\
\hline $\mathrm{NaOCl}+\mathrm{EES}$ & $4.79(4.20 \pm 5.43) \mathrm{Aa}$ & $4.33(4.08-4.62) \mathrm{Aa}$ & 72.46 & $0.78(0 \pm 0.85) \mathrm{Bb}$ & 99.99 & $0.30(0 \pm 0.51) \mathrm{Bb}$ & 99.99 \\
\hline
\end{tabular}

Sample collections (C): Baseline (C1); following electrofulguration with the Endox ${ }^{\oplus}$ Endodontic system (EES) (C2); following chemo-mechanical preparation (C3); after final EES treatment (C4). CHX, 2\% chlorhexidine gel; $\mathrm{NaOCl}$, 5.25\% sodium hypochlorite. Different capital letters indicate differences at the 0.05 level between groups for each collection time (compared by Kruskal-Wallis and Dunn's post hoc tests); different low case letters indicate differences at the 0.05 level between collections within the same group (compared by Wilcoxon signed-rank and Friedman tests). 
After CMP, all groups showed significant bacterial counts reduction $(p<0.05)$, with greater killing observed in $\mathrm{CHX}$ and $\mathrm{NaOCl}$-treated samples as compared to saline-treated samples. No significant difference was observed in the treatments with $\mathrm{CHX}$ and $\mathrm{NaOCl}$ following $\mathrm{CMP}(\mathrm{p}>0.05)$. All $\mathrm{CHX}$ and $\mathrm{NaOCl}$-treated groups mostly presented negative samples of microbial growth. Meanwhile groups treated with saline solution had all positive samples for bacteria growth.

Lastly, treatment with the EES following CMP (C4) did not significantly reduce the amount of $\mathrm{CFU} / \mathrm{mL}$ in the root canal (C3 vs. $\mathrm{C} 4, \mathrm{p}>0.05)$.

\section{Discussion}

In the present study it was tested the ability of the Endox ${ }^{\circledR}$ Endodontic System, in combination or not with ACS, to reduce E. faecalis cells colonizing the root canal surfaces. This system works by electrofulguration, in which an electrical pulse emitted inside the root thirds produces lethal damage to the bacterial cell membrane (10). While endodontic infections have a polymicrobial nature, with a predominance of Gram-negative anaerobic bacteria, the microbiota of root canals with endodontic failure is characterized by Gram-positive facultative anaerobic bacteria, among which, E. faecalis (1).

The specimens were immersed in E. faecalis cultures under appropriate growth conditions for 21 days $(14,18)$. Different experimental times and contamination protocols are also reported in the literature. Some authors used a week of contamination $(11,12)$, while others 28 days $(23)$.

The reduction percentage obtained by Endox ${ }^{\circledR}$ in the $\mathrm{C} 2$ was lower than after the chemicalmechanical preparation of all groups (C3), ranging from 45\% to 73\%, with no difference between the groups. Endox ${ }^{\circledR}$ used alone was not as effective as when combined with instrumentation, regardless of the system and chemical concentration used, which is in agreement with other researches (11-14). A study evaluating the performance of the Endox ${ }^{\circledR}$ Endodontic System in reducing Escherichia coli LPS revealed no satisfactory results (24).

One pulse per root third was applied as instructed by the manufacturer, which is in line with the literature (14). In contrast, some studies applied different protocols regarding the pulse. Another study used 2 pulses per root third (cervical, middle and apical) (11), while another one did not specify whether they used 1 or 2 (13). A different research used 1 pulse in the cervical and middle thirds and 2 in the apical third (12). Taken altogether, the results of the studies suggest that the number of emitted pulses does not seem to influence the outcome.

The $\mathrm{Mtwo}^{\circledR}$ instrumentation system was used in this study as it features an excellent cutting capacity contributing to the removal of bacterial cells (25). When compared to other systems, including single-file reciprocating system, Mtwo ${ }^{\circledR}$ has shown excellent results (23). Here, all apical diameters were initially standardized in size 20 and instrumented up to size 35 . A previous study had shown that roots with initial apical foramen size of 15 and instrumented up to size 25 or 35 had no statistically significant difference in reducing intra-canal bacteria and both sizes could effectively reduce intra-canal bacteria (26).

In this study, there was a bacterial inhibition in the root canal lumen after CMP in all experimental groups, including those that received saline solution, agreeing with previous studies (20). Regardless of the irrigant used during the CMP, it is possible to significantly decrease the bacterial load using large amount of the irrigant. However, the greatest difficulty is to avoid recontamination of the root canal by the microorganisms located inside the dentinal tubules. Chlorhexidine- and hypochlorite-treated specimens showed higher CFU counts reduction when compared with the saline-treated specimens, which is in agreement with the literature $(20,27)$. Several studies have reported about the similar antimicrobial activity of $5.25 \% \mathrm{NaOCl}$ and $2 \% \mathrm{CHX}(27-29)$, which agrees with our findings.

It was observed a large range of values among the groups investigated, particularly in the initial samples, what means high variability of the bacterial load in the samples. This may be explained by the fact that it is quite impossible to standardize the number of bacteria that will colonize the dentinal tubules. It depends on several factors, including the diameter of the dentinal tubules. Therefore, the $\mathrm{CFU} / \mathrm{mL}$ varied among the groups.

The results showed that there is still a need for development of new root canal disinfection systems to increase the success rate of the endodontic therapy. Even though the technological advances of the instruments have brought significant improvements in the ability to shape the root canals, with less 
procedural complications; new antimicrobial agents and different irrigation / agitation systems are still needed, in order to make the reduction of intracanal bacteria more efficient, especially in complex anatomy and in non-instrumented areas of the root canal system (30).

To conclude, the use of the Endox ${ }^{\circledR}$ Endodontic System did not result in considerable bacterial killing at all operative times, while treatment with $\mathrm{NaOCI}$ and $\mathrm{CHX}$ was equally efficient for this purpose.

\section{Acknowledgements}

This work was supported by the Brazilian grant agencies Sao Paulo Research Foundation (FAPESP, finance code 2015/23479-5), Brazilian Coordination for the Improvement of Higher Education and Graduate Training Personnel (CAPES, finance code 001), National Council for Scientific and Technological Development (CNPq, finance code 308162/2014-5, 303852/2019-4). We would like to thank MSc Maicon R Z Passini for technical support.

\section{Resumo}

A descontaminação do sistema do canal radicular (CR) é essencial para o sucesso da terapia endodôntica. Neste estudo in vitro, foi avaliado o potencial de desinfecção de um dispositivo de eletrofulguração, o Endox ${ }^{\circledR}$ Endodontic System (EES), em CR infectado com Enterococcus faecalis. Sessenta e cinco pré-molares inferiores humanos foram instrumentados com o sistema MTwo ${ }^{\circledR}$. As amostras foram distribuídas em seis grupos experimentais $(\mathrm{n}=10)$, de acordo com o protocolo de irrigação: clorexidina gel a 2\% (CHX); CHX + EES; Hipoclorito de sódio 5,25\% (NaOCl); $\mathrm{NaOCl}$ + EES; solução salina (SS); e SS + EES. Cinco amostras não foram tratadas (controle). As amostras de CR foram coletadas antes (C1) e após o tratamento com EES (C2), após preparo químico-mecânico (PQM) (C3) e após o tratamento final com EES (C4). Todas as amostras foram plaqueadas para unidades formadoras de colônias (CFU / mL) em meio sólido. Os dados foram analisados pelos testes de Wilcoxon e Friedman para comparações intragrupos e pelo teste de Kruskal Wallis, seguidos pelo teste de Dunn para comparações intergrupos $(\alpha=0,05)$. 0 tratamento com o EES não reduziu significativamente o número de CFU / mL em comparação com os níveis basais (C1 vs. C2, p> 0,05). Após PQM (C3), todos os grupos apresentaram uma quantidade significativamente reduzida de CFU / $\mathrm{mL}(\mathrm{p}<0,05)$, sem diferença entre as amostras tratadas com $\mathrm{CHX}$ e $\mathrm{NaOCl}(\mathrm{p}>0,05)$. Por fim, o tratamento com o EES após PQM (C4) não reduziu significativamente a quantidade de CFU / $\mathrm{mL}$ (C3 vs. C4, p> 0,05). Concluindo, o uso do Endox ${ }^{\circledR}$ Endodontic System não resultou em redução bacteriana considerável em todos os momentos operatórios, enquanto os tratamentos com $\mathrm{NaOCl}$ e $\mathrm{CHX}$ foram igualmente eficientes para esse fim. 


\section{References}

1. Gomes BPFA, Herrera DR. Etiologic role of root canal infection in apical periodontitis and its relationship with clinical symptomatology. Braz Oral Res 2018;32(suppl 1):e69.

2. Stuart $\mathrm{CH}_{1}$ Schwartz SA, Beeson TJ, Owatz CB. Enterococcus faecalis: its role in root canal treatment failure and current concepts in retreatment. J Endod 2006;32(2):93-8.

3. Siqueira Junior JF, Rôças IN, Marceliano-Alves MF, Pérez AR, Ricucci D. Unprepared root canal surface areas: causes, clinical implications, and therapeutic strategies. Braz Oral Res 2018;32 (suppl 1):e65.

4. Iandolo A, Dagna A, Poggio C, Capar I, Amato A, Abdellatif D. Evaluation of the actual chlorine concentration and the required time for pulp dissolution using different sodium hypochlorite irrigating solutions. J Conserv Dent 2019;22(2):108-13.

5. Ballal NV, Das S, Rao BSS, Zehnder M, Mohn D. Chemical, cytotoxic and genotoxic analysis of etidronate in sodium hypochlorite solution. Int Endod J 2019;52(8):1228-34.

6. Zandi $H$, Petronijevic N, Mdala I, Kristoffersen AK, Enersen $M$, Rocas IN, et al. Outcome of endodontic retreatment using 2 root canal irrigants and influence of infection on healing as determined by a molecular method: a randomized clinical trial. J Endod 2019;45(9):1089-98.e5.

7. Salas H, Vieira GCS, Palomino I, Valero J, Pacheco-Yanes J, Campello AF, et al. Outcome of endodontic treatment with chlorhexidine gluconate as main irrigant: A case series. Aust Endod J 2020;46(3):307-14.

8. Ng YL, Mann V, Gulabivala K. A prospective study of the factors affecting outcomes of nonsurgical root canal treatment: part 1: periapical health. Int Endod J 2011;44(7):583-609.

9. Haffner C, Folwaczny M, Galler K, Hickel R. Accuracy of electronic apex locators in comparison to actual length--an in vivo study. J Dent 2005;33(8):619-25.

10. Cassanelli C, Marchese A, Cagnacci S, Debbia EA. Alteration of membrane permeability of bacteria and yeast by high frequency alternating current (HFAC). Open Microbiol J 2008;2:32-7.

11. Virtej A, MacKenzie CR, Raab WH, Pfeffer K, Barthel CR. Determination of the performance of various root canal disinfection methods after in situ carriage. J Endod 2007;33(8):926-9.

12. Karale R, Thakore A, Shetty V. An evaluation of antibacterial efficacy of $3 \%$ sodium hypochlorite, high-frequency alternating current and 2\% chlorhexidine on Enterococcus faecalis: An in vitro study. J Conserv Dent 2011;14(1):2-5.

13. Mammani IMA, Mohammod JMN, Saleh ZE. Efficacy of Endox Endodontic System in eradication of Enterococcus faecalis from Infected Pulp in Duhok, Kurdistan, Iraq. Rawal Medical J 2010;35(1):4850 .

14. Aranda-Garcia AR, Guerreiro-Tanomaru JM, Faria-Junior NB, Chavez-Andrade GM, Leonardo RT, Tanomaru-Filho $M$, et al. Antibacterial effectiveness of several irrigating solutions and the Endox Plus system - an ex vivo study. Int Endod J 2012;45(12):1091-6.

15. Schneider SW. A comparison of canal preparations in straight and curved root canals. Oral Surg Oral Med Oral Pathol 1971;32(2):271-5.

16. Perez $F$, Calas $P$, de Falguerolles $A$, Maurette A. Migration of a Streptococcus sanguis strain through the root dentinal tubules. J Endod 1993;19(6):297-301.

17. Prado M, Santos Júnior HM, Rezende CM, Pinto AC, Faria RB, Simão RA, Gomes BP. Interactions between irrigants commonly used in endodontic practice: a chemical analysis. J Endod. 2013; 39(4):505510.

18. Research Randomizer (Version 4.0)[Computer software]. [Internet]. 2013.

19. Haapasalo $M$, Orstavik D. In vitro infection and disinfection of dentinal tubules. J Dent Res 1987;66(8):1375-9.

20. Berber $V B$, Gomes BP, Sena NT, Vianna ME, Ferraz CC, Zaia AA, et al. Efficacy of various concentrations of $\mathrm{NaOCl}$ and instrumentation techniques in reducing Enterococcus faecalis within root canals and dentinal tubules. Int Endod J 2006;39(1):10-7.

21. Siqueira JF, Jr., Rocas IN, Favieri A, Lima KC. Chemomechanical reduction of the bacterial population in the root canal after instrumentation and irrigation with 1\%,2.5\%, and 5.25\% sodium hypochlorite. J Endod 2000;26(6):331-4.

22. Marinho AC, Martinho FC, Gonçalves LM, Rabang HR, Gomes BP. Does the Reciproc file remove root canal bacteria and endotoxins as effectively as multifile rotary systems? Int Endod J 2015;48(6):5428.

23. Ferrer-Luque CM, Bejarano I, Ruiz-Linares M, Baca P. Reduction in Enteroccocus faecalis counts - a comparison between rotary and reciprocating systems. Int Endod J 2014;47(4):380-6. 
24. Melo TAF, Grundling GSL, Montagner F, SCUR AL, Steier L, Scarparo RK, et al. LPS levels in root canals after the use of ozone gas and high frequency electrical pulses. Braz Oral Res 2016;30:S180683242016000100231.

25. Schafer E, Erler M, Dammaschke T. Comparative study on the shaping ability and cleaning efficiency of rotary Mtwo instruments. Part 2. Cleaning effectiveness and shaping ability in severely curved root canals of extracted teeth. Int Endod J 2006;39(3):203-12.

26. Mohammadzadeh Akhlaghi N, Rahimifard N, Moshari A, Vatanpour M, Darmiani S. The effect of size and taper of apical preparation in reducing intra-canal bacteria: A quantitative SEM study. Iran Endod J 2014;9(1):61-5.

27. Vianna ME, Gomes BP, Berber VB, Zaia AA, Ferraz CC, de Souza-Filho FJ. In vitro evaluation of the antimicrobial activity of chlorhexidine and sodium hypochlorite. Oral Surg Oral Med Oral Pathol Oral Radiol Endod 2004;97(1):79-84.

28. Ercan E, Ozekinci T, Atakul F, Gül K. Antibacterial activity of $2 \%$ chlorhexidine gluconate and 5.25\% sodium hypochlorite in infected root canal: in vivo study. J Endod 2004;30(2):84-7.

29. Gomes BPFA, Vianna ME, Zaia AA, Almeida JFA, Souza-Filho FJ, Ferraz CCR. Chlorhexidine in endodontics. Braz Dent J 2013;24:89-102.

30. Gomes BPFA, Rôças IN, Siqueira JF Jr. Endodontic infections and therapeuthical approaches. In: Oral Microbiology and Immunology. ASM Press. 3rd ed. Washington: Lamont RJ, Hajishengallis G, Hyun MK, Jenkinson HF; 2019. p 419-434. 